\title{
Readiness Retirement Based on Sex, Position and Family Social Support
}

\author{
Wia Septia ${ }^{1 *}$, Herman Nirwana ${ }^{2}$, Afdal Afdal ${ }^{3}$ \\ Universitas Negeri Padang ${ }^{123}$ \\ *) Correspondence Author, e-mail: wiaseptia@gmail.com
}

\begin{abstract}
Readiness for retirement based on sex, position and family social support and its implications for Guidance and Counseling services. This study aims to describe the readiness to face retirement in civil servants in terms of sex, position and family social support. The sample used in this study were 40 civil servants who would retire in various government agencies in Padang Panjang City, West Sumatra. This research uses Proportional Random Sampling technique. The instrument used in this study was a scale of readiness retirement with a reliability of 0.893 and a scale of family social support with a reliability of 0.941 . The findings show that there is no difference in readiness retirement in terms of sex, position and family social support. This shows that there are other factors that can affect a person's retirement readiness. These factors are age, education level, race, ethnicity and personality. Self-efficacy is a personality dimension which is an individual's assessment of his or her ability or competence to do a task, achieve a goal, and produce something.
\end{abstract}

Keywords: Readiness retirement, sex, position, family social support

Article History: Received on 09/03/2020; Revised on 09/06/2020; Accepted on 13/06/2020; Published Online: 11/7/2020.

This is an open access article distributed under the Creative Commons Attribution License, which permits unrestricted use,
distribution, and reproduction in any medium, provided the original work is properly cited. (C2020 by author.

\section{INTRODUCTION}

Retirement is often seen as an unpleasant reality so that by the time that time comes some people are anxious and not ready to face the situation (Hurlock, 2007). Readiness to retirement is necessary for a worker because physically weakened and mentally, a worker who is going to retire will usually feel a loss of position, a feeling of less respect for others for himself, reduced income, incomplete living facilities, and unable to adjust to himself. Environment and new situations during retirement (Cristian \& Moningka, 2012; Wulandari, 2011).

Readiness to retirement according to Safitri (2013) is a cognitive marker of behavior from rejection or support for change efforts and maturity points in the form of readiness, readiness, maturity to be able to accept a transition period to a new lifestyle, in this case always involves changing roles, changing desires and values, and overall changes to individual life patterns that manifest in the form of behavior. A survey from HSBC in 2014 stated that half of people in Indonesia said they were not ready to retire. The results of the Aegon Center Longevity and Retirement survey to 15 countries show that the country's average pension readiness index in 2015 is in the low score category, which means that 
respondents have a tendency to be unprepared for retirement (Sagala \& Saputra, 2016). The survey is reinforced by the results of preliminary research in 2020 obtained from several retired civil servants in West Sumatra. These results indicate that $46.7 \%$ of civil servants experience unpreparedness in facing retirement. Research by Cristian \& Moningka (2012) reveals that the party most afraid of facing retirement is Civil Servants (PNS).

Readiness retirement is influenced by many factors. Some of these factors are gender, position and family social support (Harper, 2005: Kim \& Moen, 2002). These factors are considered important because these factors are in the Career Counseling Guidance. In career counseling guidance, gender and position have an important role in an individual's career. Meanwhile, family social support has an important effect on an individual's career in old age, especially when facing retirement where his physical and financial conditions will decline. So that the three variables are a combination that has an influence on the readiness to face individual retirement.

In the research of Brewster \& Padavic (2000) and Inglehart \& Norris (2003) that the focus of research on sex differences in retirement planning has changed markedly over the past century because Western societies have seen a shift in gender roles with respect to employment and retirement. Traditional gender roles place jobs and pensions dominated by men. Although after World War II female workers experienced an increase, research over the next two decades has consistently shown that women undertake less retirement planning than men (Atchley; Kilty \& Behling, in Noone, et al, 2016). Arnold (2005) also revealed that women and men tend to have different career development paths, in career theory and practice reflect the perspective of men better than women.

The results of research conducted by Mansor, Shaari \& Abu (2015) state that men and women have different readiness to face retirement. Men tend to be more prepared to retire than women because men tend to discuss more so they have knowledge about managing finances. In line with previous research, research by Kim \& Moen (2002) states that women are more prone to stress than men when they are about to enter retirement age because women feel inadequate financially due to low salaries and have more complicated and less insightful careers. in financial management.

Career is defined as the sequence of positions, positions, main jobs occupied by individuals from pre-work (education), work, to post-work life (retirees) by Healey (1982). This means that the position is an important part of a career. A person holding a position in his career is less ready to retire than someone who is on staff. During the working period, structural officials are synonymous with adequate service facilities, assistants, extensive relationships and high income so that after retirement these facilities are no longer obtained (Rini, in Biya \& Suarya, 2016; Hermaningtyas, Mardijana \& Dewi, 2015 ; Syamsir, 2009).

The position held can affect the strength of an individual's self-esteem and social status. When a civil servant will retire, the civil servant will also lose his position. Losing one's position means losing money, facilities, self-respect and social status in society. Unpreparedness to retire will arise because someone is not only afraid of losing these things but also because someone does not know what will happen in the next life after 
retirement (Atchley, in Reizes \& Mutran, 2004). In a study conducted by Wahrendorf, Dragano \& Siegrist (2012), it was found that in 11 European countries, the results of the importance of job position and the quality of the work environment for someone who is about to retire. So that by improving the quality of work and providing part-time work opportunities, it will minimize stress on workers who are about to enter retirement.

Social support is one of the supporting factors in an individual's career in old age. This factor comes from outside the individual which affects retirement readiness so that it will lead to the psychological well-being of the individual (Kim \& Moen, 2002). Research conducted by Robbin, Lee \& Wan (Herr, et al, 2004) states that social support is the most important factor in facing retirement. The results of Kadarisman's (2011) study state that the wives of civil servants who are about to retire also experience stress because the husband's attitude changes psychologically before entering retirement, thus making the problem even more severe. Biya \& Suarya (2016) stated that the higher the social support provided to structural officials who are about to retire, the more prepared these officials are to face their retirement.

Career Counseling Guidance according to Super (Herr, Cramer \& Niles, 2004) states that research on jobs and careers focuses more on the sexes of men and women such as gender role stereotypes, ethnicity, culture and individual differences. So that career counseling counselors are expected to be able to understand the differences in gender roles, different positions held and family social support received by these individuals to be applied when providing services in dealing with civil servants who are about to retire.

\section{METHOD}

This research uses quantitative research methods with descriptive comparative research type with a factorial model design. The research population is 69 civil servants who will retire in the city of Padang Panjang. The sample in this study is 40 civil servants who will retire, divided into gender and position. Withdrawal of samples using proportional random sampling technique. The instrument used was a scale of retirement readiness with a reliability of 0.893 and a scale of family social support with a reliability of 0.941. To determine the difference between the independent variable and the dependent variable, it was analyzed using analysis of variance (ANOVA). Data analysis was assisted by using the Statistical Product and Service Solution (SPSS) program version 20.0.

\section{RESULT AND DISCUSSION}

Research data on readiness to face retirement in terms of gender, position and family social support. The results can be seen in the following table:

Table 1. Hypotheses of differences in readiness retirement based on sex

\begin{tabular}{lllllll}
\hline SEX & $\boldsymbol{M}$ & $\mathbf{d f}$ & MS & F & Sig. & Information \\
\hline Male & 3,4 & 1 & 604,6 & 21,94 & 0,00 & Significant \\
Female & 3,2 & & & & & \\
\hline
\end{tabular}


Table 2. Hypotheses of differences in readiness retirement based on position.

\begin{tabular}{lllllll}
\hline Position & $\mathbf{M}$ & $\mathbf{d f}$ & $\mathbf{M S}$ & $\mathbf{F}$ & Sig. & Information \\
\hline Structural & 66,10 & 1 & 204,5 & 7,4 & 0,01 & Significant \\
Staff & 70,55 & & & & & \\
\hline
\end{tabular}

Table 3. Hypotheses of differences in readiness retirement based on family social support

\begin{tabular}{lllllll}
\hline $\begin{array}{l}\text { Social } \\
\text { Support }\end{array}$ & $\mathbf{M}$ & $\mathbf{d f}$ & MS & F & Sig. & Information \\
\hline High & 68,0 & 2 & 11,6 & 0,42 & 0,66 & Not Significant \\
Medium & 68,7 & & & & & \\
Low & 66,8 & & & & & \\
\hline
\end{tabular}

Table 4. Hypothesis of differences in readiness retirement is based on gender, position and family social support

\begin{tabular}{lllllll}
\hline Variabel & N & df & MS & F & Sig & Information \\
\hline Gender & 40 & 1 & 0,809 & 0,029 & 0,865 & $\begin{array}{l}\text { Not } \\
\text { Significant }\end{array}$
\end{tabular}

Based on table 1, it shows a significance value of 0.00 . If the significance level is less than 0.05 , it is significant so that the hypothesis is that there are differences in civil servant retirement readiness based on gender. The mean value shows that men are greater by 66.30 and women with a value of 65.90 . This means that men are more prepared to face retirement than women.

In the second table, a significance level of 0.01 is obtained, which means that the value is less than 0.05 , which indicates significant. This means that the hypothesis is that there are differences in readiness to face retirement in terms of position. The mean value of staff positions (70.55) is higher than the mean structural positions (66.10). This means that civil servants with staff positions are better prepared to face retirement than civil servants with structural positions.

In the third table, the results of the significance level are 0.66 , which means there is no difference in readiness to face retirement in terms of family social support. Each of these mean values in order from high to low are moderate social support (68.73), high social support (68.00) and low social support (66.88). This means that readiness to face retirement has no effect on the family social support that these civil servants receive. 
In the fourth hypothesis, it is found that the significance level is 0.82 which means it is not significant. So it can be explained that there is no difference in readiness to face retirement in terms of gender, position and family social support.

\section{Discussion}

Based on the results of hypothesis testing using the ANOVA technique related to readiness to face retirement based on gender, position and family social support, the value of $F=0,029$ and a significance value of 0.865 is obtained so that it can be concluded that there is no significant difference in readiness to face retirement based on gender, position and family social support. This means that readiness for retirement can be influenced by other factors.

The results showed that the readiness to face retirement for men and women was different. First, from a physical point of view, men experience physical decline more slowly than women. Physical decline will have an impact on individual psychology. So that men are physically and psychologically stronger in facing retirement (Harber, 2010). Second, from an economic point of view. Research by Noone, et al (2010) and Mansoor, et al (2015) stated that there are differences in readiness to face retirement between men and women, where men are more prepared to face retirement than women because of men's knowledge of finances, personal savings, pension funds and pension investment are higher than for women.

\section{CONCLUSIONS}

The conclusion of this study is that there is no difference in readiness to face retirement based on family social support and readiness to face retirement in civil servants based on gender, position and family social support belonging to the low category. Therefore, there are other factors that affect civil servants' readiness to face retirement.Thus, it is hoped that the government will establish a special formation for counselors to assist retired civil servants in preparing for their retirement. For counselors to be able to assist civil servants who are facing retirement by providing services that are tailored to the civil servants gender, position and family social support. In addition, the counselor can provide counseling guidance services according to the items on the readiness to face retirement instrument and the family social support sub-variables which are classified as low to very low.

\section{REFERENCES}

Arnold, L. M., Rosen, A., Pritchett, Y. L., D'Souza, D. N., Goldstein, D. J., Iyengar, S., \& Wernicke, J. F. (2005). A randomized, double-blind, placebo-controlled trial of duloxetine in the treatment of women with fibromyalgia with or without major depressive disorder. Pain, 119(1-3), 5-15.

Bandura, A. (1986). Social Foundations Of Thought And Action; A Social Cognitive Theory. New Jersey: Prentice-Hall. 
Baron, R,. \& Byrne. (2004). Psikologi Sosial. Jakarta: Erlangga

Biya, C. I. M. J., Suarya, L. M. K. S., \& Psi, S. (2016). Hubungan dukungan sosial dan penyesuaian diri pada masa pensiun pejabat struktural di pemerintahan Provinsi Bali. Jurnal Psikologi Udayana, 3(2), 354-362.

Brewster, K. L., \& Padavic, I. (2000). Change in gender-ideology, 1977-1996: The contributions of intracohort change and population turnover. Journal of Marriage and Family, 62(2), 477-487.

Christian, C., \& Moningka, C. (2012). Self Efficacy dan Kecemasan Pegawai Negeri Sipil Menghadapi Pensiun. Jurnal Psikologi Ulayat: Indonesian Journal of Indigenous Psychology, 1(1) 45-56.

Haber, D. (2010). Health Promotion and Aging: Practical Applications for Health Professionals, Fifth Edition. New York: Springer Publishing Company.

Harper, M. C. (2005). Retirement modeling: An exploration of the effects of retirement role model characteristics on retirement self-efficacy and life satisfaction in midlife workers. The University of North Carolina at Greensboro.

Hasler, A., \& Lusardi, A. (2017). The gender gap in financial literacy: A global perspective. Global Financial Literacy Excellence Center, The George Washington University School of Business.

Herr, Cramer \& Niles. (2004). Career Guidance and Counseling Through the Life Span: Systematic approaches. New York: Harper Collins.

Hurlock, Elizabeth B., (2007). Psikologi Perkembangan Suatu Pendekatan Sepanjang Rentang Kehidupan edisi kelima. Jakarta: PT Erlangga.

Inglehart, R., Norris, P., \& Ronald, I. (2003). Rising tide: Gender equality and cultural change around the world. Cambridge University Press.

Kadarisman, M. (2011). Menghadapi pensiun dan kesejahteraan psikologis pegawai negeri sipil. Civil Service Journal, 5(2 November).

Kim, J. E., \& Moen, P. (2002). Retirement transitions, gender, and psychological wellbeing: A life-course, ecological model. The Journals of Gerontology Series B: Psychological Sciences and Social Sciences, 57(3), 212-222.

Mansor, M. F., Hong, C. C., Abu, N. H., \& Shaari, M. S. (2015). Demographic factors associated with retirement planning: a study of employees in Malaysian Health Sectors. Asian Social Science, 11(13), 108.

Safitri, B. R. (2013). Kesiapan Menghadapi Masa Pensiun Ditinjau Dari Peran Gender Karyawan. Jurnal Ilmiah Psikologi Terapan, 1(2), 191-204.

Santrock, J.W. (2007). Human Adjustment. University of Texas at Dallas. Mc Graw Hill Companies.

Saputra, H. R., \& Sagala, E. J. (2016). Pengaruh Program Persiapan Pensiun Terhadap Kesiapan Pensiun Karyawan Di Pt Krakatau Steel (persero) Tbk. eProceedings of Management, 3(3).

Serrat, R., Villar, F., Pratt, M. W., \& Stukas, A. A. (2018). On the quality of adjustment to retirement: The longitudinal role of personality traits and generativity. Journal of personality, 86(3), 435-449.

Super, D. E. (1980). A life-span, life-space approach to career development. Journal of vocational behavior, 16(3), 282-298. 
56 Readiness Retirement Based on Sex, Position and Family Social Support

Sutarto, J. T,. \& Cokro, I.(2008). Pensiun Bukan Akhir Segalanya. Jakarta: Gramedia Pustaka Utama.

Wulandari, M. (2016). Dukungan keluarga pada karyawan yang mengalami kecemasan menjelang masa pensiun. Jurnal Psikoboreno, 4(4). 